University of Michigan Law School

University of Michigan Law School Scholarship Repository

Articles

Faculty Scholarship

1914

\title{
Jurisprudence: A Formal Science
}

Joseph H. Drake

University of Michigan Law School

Available at: https://repository.law.umich.edu/articles/1354

Follow this and additional works at: https://repository.law.umich.edu/articles

Part of the Jurisprudence Commons, and the Law and Philosophy Commons

\section{Recommended Citation}

Drake, Joseph H. "Jurisprudence: A Formal Science." Mich. L. Rev. 13 (1914): 34-6.

This Response or Comment is brought to you for free and open access by the Faculty Scholarship at University of Michigan Law School Scholarship Repository. It has been accepted for inclusion in Articles by an authorized administrator of University of Michigan Law School Scholarship Repository. For more information, please contact mlaw.repository@umich.edu. 
Jursprudence: A Formai, Science--Holiand defines jurisprudence as "the formal science of positive law" ("JuRISPRUdFNCE," Ioth ed., p. I3). The meaning of science is plain enough. A good many pages are devoted to the elucidation of the words "positive" and "law," but the term "formal" he explains only by analogy. As there is a formal science of grammar to which belongs, for example. the concept of possession, which has its material manifestation in Latin grammar in a genetive termination and in English grammar in the preposition "of," so there is a formal science of law, material manifestations of whose fundamental principles are found in various systems of actual legal rules. It is manifest that formal is used here as the synonym of essential, and if the latter word were substituted for the former it would materially clarify the definition for many students of jurisprudence. In a forthcoming volume of the "LEGAL PhILOSOPHy SERIEs" (Volume $X$ ) the Italian of DEL VECCHIO's title, "I presupposti filosophici della notizione del diritto" is paraphrased as "The Formal Bases of Law," and as there is likely to be the same difficulty of interpretation here as in HoLLAND's definition some account may not be amiss as to why formal means essential as well as non-essential and how it came to have the two opposite meanings.

It may be noted that the use of formal as the synonym of essential seems to be peculiar to philosophic nomenclature and it may therefore be surmised that we must go to ancient philosophy for an explanation. Juristic philosophers as well as metaphysicians in general have always set before themselves the task of getting at the ultimate truth back of their subject, and although it is a brave man that would attempt to define philosophy or to formulate the ultimate purpose of philosophers, still as we'go back over the history of the subject they all seem to be striving to get an answer to PILATE's question: "What is truth?" What is the real essence of things? What do we mean when we say a thing "is"? What is that something that we must think by virtue of our common intelligence-that something that is true for all times and in all places? The juristic philosopher, like his brother the pure metaphysician, in asking this question. $\mathrm{He}$ is 
seeking the ultimate reality in his subject, law. We have had various formulations of this absolute reality. Plato called it ióé (the idea), which may be explained by an illustration from mathematics. The circle that we draw is not the real circle but only a copy of the true reality. The "idea" of circle is the mathematical concept of curved and continuous line, each point of which is connected, by radii of equal length, with the central point. This concept existed before any circle was made and would exist if none ever were drawn. It is therefore a true absolute, the something that eternally is. Aristorle, the great successor of PLATo, called his absolute ovo'a, which is etymologically our "essence." The distinction between the concepts of ARISTOTLE and of PLATo is for our purpose immaterial. The significant thing about the concepts is that each is an absolute, a philosophic reality.

When CICERo was driven out of politics by the more practical politicians of his day, he betook himself to the consolations of the classical analogue of religion, namely, philosophy; and while no one, except CrcERo himself, has ever thought he was a great philosopher, he performed a very important service for philosophy in that he gave to Greek philosophic nomenclature a proper Latin dress. We should naturally expect therefore to find in the works of Cicero the Latin equivalent of the iséa of PLATO and the ovoría of ARISTOTLE, and we are not disappointed. We find that he used the word "forma" as the equivalent of one of these absolutes. "De Orat." Io "has rerum formas appellat ióéas Plato easque gigni negat et ait semper esse ac ratione et intelligentia contineri" ("These forms of things PLATo calls ideas and he says that they are not born but that they always are [esse] and that they are comprehended by reason and intelligence").

Here the Ciceronian "forma" is evidently made equal to the Platonic "idea." CrCERo does not seem to have given any such exact definition of the Aristotelian absolute, at least no translation of ovjoía as "forma" appears in any of the lexicons of CicrRo, but we have in his description of the Platonic absolute the statement that it is the essence of things (esse), and this justifies us in writing the equation, "forma" = "essens." It may be observed that this participle of the verb "esse" is hardly classical in origin. Cicero apparently does not use it at all. Even the abstract "essentia" occurs only in the "Fragmenta" (cf. Fr. K. ro, ed. C. F. W. Mueller). Mediaeval philosophy, however, coined two participles from the classical "esse," namely, "ens," which appears in our word "entity" and "essens" from which comes "essential." The word "essentia" is constantly used throughout the Middle Ages as the equivalent of the Aristolelian ovoria and it appears in modern romance languages with the same meaning as in English.

The genealogy of the word "formal" as the equivalent of "essential" is thus perfectly plain and its use in this sense by such classically trained scholars as HOLLAND and DEL VECCHIo is what might be expected. HolLAND's "formal science" is the science of essential principles, and DEL VECCHIo describes the formal basis of law as "the eternal seed of justice, the foundation of the idea of law . . . not furnished by nature as the complex or succession of empirical facts but by the essence or nature of man." 
The real difficulty is to explain the use of formal in its everyday sense as the opposite of essential, as when we say, "the distinction is merely formal but there is no real difference." There seems to be some squinting at this in the use of the word ióa by PLATo which contains the root of the Greek equivalent of our word "see." We see only what is superficial and not the real essence of the thing, but this side of the concept was apparently not prominent in PLATo's mind and although ARISTOTLE calls cidos the "form," he means by it not the outward appearance but the sum of its specific determinants by virtue of which a thing is what it is. The medizvalists use formal generally in the sense of essential while all the examples of English usage given by the Oxford Dictionary of the meaning superficial or non-essential come from a comparaively late period. This may or may not be indicative of the fact that its use in this sense has developed in modern times.

J. H. D. 